\title{
Varicella Zoster Virus Antibody Measurement
}

National Cancer Institute

\section{Source}

National Cancer Institute. Varicella Zoster Virus Antibody Measurement. NCI Thesaurus.

Code C117867.

The determination of the amount of total Varicella Zoster virus antibody present in a sample. 